\title{
Evaluasi Kebijakan Mendirikan Bangunan di Kecamatan Tondano Selatan Kabupaten Minahasa
}

\author{
Marthinus Mandagi*, Sisca Kairupan ${ }^{\text {a, } 1}$ \\ ${ }^{a}$ Universitas Negeri Manado, Prodi Ilmu Administrasi Negara, Kota Manado, Indonesia \\ ${ }^{1}$ marthinusmandagi@unima.ac.id*; ${ }^{2}$ siscakairupan@unima.ac.id
}

IN F O A R T I K E

Key word:

IMB Policy,

Evaluation,

PDUPT.

\section{A B S T R A C T}

The general purpose of carrying out this research is to describe and analyze the evaluation of building permit policies in the city of Tondano, PDUPT Activities Evaluation of Building Permit Policies in South Tondano District, Minahasa Regency using a qualitative approach, where this approach method explores and understands the meaning that comes from social problems or problems. humanity relevant to the research focus. The results found are: 1) Government officials do not know much about the process of evaluating building permit policies; 2) Of the many buildings in the District of South Tondano, amounting to 350, only 10 buildings already have permits; 3) Lack of socialization from the government has led to low public awareness in obtaining building permits in the south tondano sub-district; 4) Until now there has been no action from government officials regarding buildings that do not have in the sub-district of West Tondano because housing was once made for the relocation of people along the Lake Tondano border, but in the process the lack of government supervision has made the same thing happen again.

\section{INTISARI}

\section{Kata kunci:}

Kebijakan IMB,

Evaluasi,

PDUPT.
Tujuan umum dilaksanakannya penelitian ini adalah untuk mendeskripsikan dan menganalisis Evalluasi kebijakan izin mendirikan bangunan di kota Tondano, Kegiatan PDUPT Evaluasi Kebijakan Izin Mendirikan Bangunan di Kecamatan Tondano Selatan Kabupaten Minahasa menggunakan Pendekatan Kualitatif, dimana Metode Pendekatan ini mengeksplorasi dan memahami makna yang berasal dari permasalahan sosial atau kemanusiaan yang relevan dengan fokus penelitian. Hasil yang ditemukan adalah: 1) Para aparat pemerintah kurang mengetahui tentang proses evaluasi kebijakan ijin mendirikan bangunan; 2) Dari sekian banyak Bangunan di Kecamatan Tondano Selatan yang berjumlah 350 hanya 10 bangunan yang telah memiliki izin; 3) Kurangnya sosialisasi dari pemerintah membuat rendahnya kesadaran masyarakat dalam pengurusan ijin mendirikan bangunan di kecamatan tondano selatan; 4) Sampai saat ini belum ada lagi tindakan dari aparatur pemerintah terkait bangunan yang tidak memiliki di kecamatan tondano barat karena dulu pernah dibuat perumahan untuk relokasi masyarakat disempadan danau tondano,namu dalam prosesnya kurangnya pengawasan pemerintah membuat hal yang sama terjadi kembali. 


\section{Pendahuluan}

\subsection{Latar Balakang}

Danau adalah bagian dari sungai yang lebar dan kedalamannya secara alamiah jauh melebihi ruas-ruas lain dari sungai yang bersangkutan. Danau Tondano adalah danau terluas di provinsi Sulawesi Utara Indonesia. Danau ini diapit oleh pegunungan lembean,gunung kaweng,bukit tampusu dan gunung masarang. Danau ini dilingkari dengan jalan provinsi dan menghubungkan kota tondano, kecamatan tondano timur kecamatan eris kecamatan kakas kecamatan remboken dan kecamatan Tondano Selatan. Danau ini merupakan danau penghasil ikan air tawar seperti ikan mujair,pior/kabos,udang

kecil,tawes,pongkor,bontayan,lobster

hitam,gurame kupu-kupu,dan ikan karper. Luas danau ini $4.278 \mathrm{ha} / 42.78 \mathrm{~km} 3$ dan terdapat pulau kecil bernama likri depan desa tandengan kecamatan eris dan pulau papalembet dekat toulumembet di tepi danau tondano [1].

Sempadan danau adalah luasan lahan yang mengelilingi dan berjarak tertentu dari tepi badan danau yang berfungsi sebagai kawasan pelindung danau, Pasal 11 Garis sempadan mata air sebagaimana dimaksud dalam Pasal 4 ayat (2) huruf $f$, ditentukan mengelilingi mata air paling sedikit berjarak 200 (dua ratus) meter dari pusat mata air. Pasal 12 (1) Garis sempadan danau ditentukan mengelilingi danau paling sedikit berjarak 50 (lima puluh) meter dari tepi muka air tertinggi yang pernah terjadi. (2) Muka air tertinggi yang pernah terjadi sebagaimana dimaksud pada ayat (1), menjadi batas badan danau. (3) Badan danau sebagaimana dimaksud pada ayat (2), merupakan ruang yang berfungsi sebagai wadah air [2]. kewenangan pemerintah dalam mengatur sempadan danau tercantum dalam peraturan menteri pekerjaan umum dan perumahanan rakyat Republik Indonesia Nomor 28/prt/m/2015 pasal 20 tentang penetapan garis sempadan sungai dan garis sempadan danau dan peraturan daerah provinsi Sulawesi utara No.11 tahun 2006 tentang sempadan sumber air [3].

Izin mendirikan bangunan adalah perizinan yang diberikan oleh pemerintah kabupaten/kota kepada pemilik bangunan gedung untuk membangun baru,memperluas,mengurangi,dan/atau merawat bangunan gedung sesuai dengan persyaratan administrative dan persyaratan teknis yang berlaku,persyaratan untuk memiliki IMB adalah 1.persyaratan administrative, 2.persyaratan peruntukan dan intensitas bangunan gedung, 3 . Persyaratan arsitektur bangunan gedung, 4. Persyaratan dampak lingkungan, yang diatur dalam Undang-Undang No.26 tahun Tentang penataan ruang dan Undang-Undang No.28 Tahun 2002 tentang bangunan gedung, dan
Peraturan Pemerintah No.36 tahun 2005 Tentang bangunan Gedung [4].

Menurut data yang didapat dari Dinas perizinan Minahasa, jumlah bangunan yang memiliki izin di Minahasa sebanyak 1317 bangunan, dan jumlah keseluruhan bangunan rumah tinggal di Minahasa menurut BPS minahasa sebanyak 56115 bangunan, sementara data bangunan Kecamatan Tondano Selatan sebanyak 350 bangunan, dan yang mempunyai IMB hanya sekitar 10 bangunan, dari data tersebut,ternyata masih banyak bangunan yang tidak memiliki izin, terutama disempadan danau tondano khususnya di Kecamatan Tondano Selatan.

Danau sangat penting bagi kehidupan manusia, untuk itu pemerintah membuat kebijakan tentang sempadan danau, agar ekosistem danau tidak terganggu dan tercemari, namun dalam kenyataannya tidak sesuai dengan apa yang diharapkan,pembangunan rumah tinggal dan restoran di sempadan danau tondano khususnya di Kecamatan Tondano Selatan sangat mempengaruhi ekosistem danau,selain mempersempit danau,kotoran dari rumah tinggal juga mempengaruhi kebersihan air di danau, bahkan menurut data yang di dapat di badan pengelolaan lingkungan hidup sulut terjadi pendangkalan danau seiring berjalannya waktu dan sangat berpotensi terjadinya banjir atau luapan air danau karena danau tidak mampu lagi menampung Air hujan yang berlebihan.

Berdasarkan latar belakang tersebut, maka perlu dilakukan penelitian tentang kebijakan izin mendirikan bangunan yang dampaknya tidak hanya pada Evaluasi kebijakan ijin mendirikan bangunan tetapi juga mencakup seluruh aspek kehidupan masyarakat, maka di rumuskan masalah sebagai berikut.

\subsection{Rumusan masalah}

Berdasarkan latar belakang masalah di atas maka dirumuskan masalah sebagai berikut : bagaimana Evaluasi kebijakan Peraturan izin mendirikan bangunan di Kecamatan Tondano Selatan.

\subsection{Tujuan penelitian}

Berdasarkan rumusan masalah tersebut, maka penelitian ini bertujuan untuk mendeskripsikan dan menganalisis Evaluasi kebijakan izin mendirikan bangunan di Kecamatan Tondano Selatan.

\subsection{Target Luaran}

1. Menemukan apa saja yang mempengaruhi Evaluasi Izin Mendirikan Bangunan di Kecamatan Tondano Selatan Kabupaten Minahasa. 
2. Untuk mengetahui dan menganalisis sistem pelayanan Izin Mendirikan Bangunan di Kantor Pelayanan Perizinan Terpadu Kecamatan Tondano Selatan.

\section{Metode Penelitian}

\subsection{Pendekatan Penelitian}

Penelitian ini menggunakan pendekatan penelitian kualitatif. Peneliti menggunakan pendekatan kualitatif. Creswell, mengatakan bahwa penelitian kualitatif merupakan metode mengeksplorasi dan memahami makna yang berasal dari permasalahan sosial atau kemanusiaan yang relevan dengan fokus penelitian. Proses penelitian kualitatif berbentuk tindakan. Tindakan tersebut menyangkut: a) prosedur mengajukan pertanyaan kepada informan, b) prosedur memperoleh dan mengumpulkan data yang spesifik dari para informan, c) mendeskripsi dan menganalisis data secara induktif yang dimulai dari tema-tema yang bersifat khusus ke tema-tema yang bersifat umum, d) melakukan penafsiran makna dari data yang diperoleh, membuat gambaran, dan e) meneliti makna kata-kata dari pandangan informan secara naturalistik [5].

Peneliti juga menggunakan pendekatan kualitatif karena cara pandang peneliti dalam mengidentifikasi suatu masalah lebih cenderung kepada pendekatan kualitatif.

Penelitian ini menggunakan metode penelitian fenomenologis, karena memandang realitas, fakta atau fenomena sosial masyarakat menjadi fokus permasalahan. Alasannya didasarkan pada tujuan penelitian yang bermaksud mengidentifikasi, mendeskripsikan dan menganalisis pemahaman informan secara menyeluruh menyangkut pengalaman sadar terhadap kebijakan ijin mendirikan bangunan.

\subsection{Waktu dan lokasi penelitian}

Lokasi penelitian ini bertempat di provinsi Sulawesi Utara, Kabupaten Minahasa, Kota Tondano Kecamatan Tondano Selatan. Peneliti mulai melakukan observasi awal pada tanggal 20 Januari 2021.

\subsection{Sumber data dan informan penelitian.}

Penelitian ini dilakukan pada Kecamatan Tondano Selatan Kabupaten Minahasa. Tujuannya adalah, untuk mengetahui mendeskripsikan impelementasi kebijakan izin mendirikan bangunan dan kebijakan tentang sempadan danau. Dalam kaitan dengan prosedur pengumpulan data, pendekatan fenomenologi-deskriptif memiliki tiga langkah strategis, yakni: intuisi, analisis, dan menjelaskan. Langkah pertama adalah intuisi. Melalui langkah ini peneliti melakukan wawancara secara mendalam tentang kepada para informan tentang realita atau fenomena sosial mengenai evaluasi kebijakan ijin mendirikan bangunan di Kabupaten Minahasa dan menghindari subjektifitas pribadi peneliti, langkah kedua adalah proses analitik. Peneliti mengetahui mendeskripsikan dan menganalisis pola impelementasi kebijakan,determinan evaluasi kebijakan ijin mendirikan bangunan. Langkah ketiga adalah proses menjelaskan. Setelah peneliti memperoleh informasi melalui wawancara mendalam dengan informan tentang pemahamannya mengenai fenomena sosial yang berhubungan dengan evaluasi ijin mendirikan bangunan, maka peneliti mendeskripsikan evaluasi kebijakan ijin mendirikan bangunan.

Prosedur atau langkah-langkah penelitian ditempuh melalui tahapan: pra-lapangan, tahap kegiatan lapangan dan tahap pasca-lapangan. Pada tahap pra lapangan, akan meliputi beberapa kegiatan yang dilakukan sebagai berikut: a) penyusunan rancangan awal penelitian, b) pengurusan izin penelitian, c) penjajakan lapangan dan penyempurnaan rancangan penelitian, d) pemilihan subjek dan informan dan e) penyiapan piranti pembantu untuk kegiatan lapangan.

Pada tahap kegiatan lapangan dilakukan pengamatan terbatas, studi dokumentasi dan wawancana mendalam (in-depth interview) sebagai teknik pengumpulan data kualitatif. Pengamatan terbatas dilakukan pada kondisi alamiah dan wajar berkaitan dengan fokus dan tujuan penelitian. Pada kegiatan wawancara mendalam (in-depth interview, semi terstruktur (lihat lampiran 2,3 dan 4), peneliti berupaya mendapatkan informasi melalui tatap muka secara fisik dan bertanya-jawab dengan informan. Dengan teknik ini, peneliti berperan sekaligus sebagai informan kunci.

Pada tahap pasca lapangan dilakukan analisis selama pengumpulan data dimaksudkan untuk mengarahkan pada fokus penelitian, mengembangkan pertanyaan-pertanyaan analitik serta memberikan dasar bagi analisis pasca pengumpulan data dimana analisis data dilakukan secara berulang-ulang.

Pada akhir pengamatan atau wawancara, dicatat hasilnya ke dalam lembar catatan lapangan yang berisi: teknik yang digunakan, waktu pengumpulan data dan pencatatannya, tempat wawancara, paparan hasil dan kesan informan.

Berdasarkan langkah-langkah tersebut di atas peneliti melakukan rekonstruksi dalam bentuk deskripsi, narasi argumentasi atau analisis dimana beberapa subtopik disusun secara deduktif dan subtopik lainnya disajikan secara induktif dan ditarik kesimpulan yang berkaitan dengan fokus dan subfokus penelitian

\subsection{Teknik Pengumpulan Data}

Teknik pengumpulan data merupakan langkah yang paling strategis dalam penelitian karena tujuan utama penelitian ini adalah mendapatkan data. Pengumpulan data dapat dilakukan dengan tahap-tahap sebagai berikut: 
1. Proses memasuki lokasi penelitian (Getting in)

Ketika memasuki lokasi penelitian, peneliti berusaha untuk mengenal kondisi dan situasi sosial dilapangan baik melalui observasi secara langsung maupun tidak langsung, karena dengan hal tersebut dapat memperlancar peneliti untuk proses pengumpulan data selanjutnya.

2. Ketika berada di lokasi penelitian (Getting along)

Ketika sudah berada dilokasi penelitian, peneliti memperkenalkan diri dan melapor mengenai maksud dan tujuan peneliti sekaligus menunjukkan semua dokumen yang berkaitan dengan ijin penelitian untuk memperoleh informasi yang selengkapnya.

3. Mengumpulkan data (Loging the data)

Pengumpulan data ini dibagi dalam 2 (dua) macam, yaitu:

- Wawancara mendalam (in-depth interview) Tujuan dari wawancara ini adalah untuk menemukan permasalah secara lebih terbuka, dimana pihak yang diajak wawancara untuk dimintai pendapat dan ide-ide. Dalam melakukan wawancara, peneliti perlu mendengarkan secara teliti dan mencatat apa yang dikemukakan oleh pemberi informasi.

- Observasi

Yaitu dengan cara melakukan pengamatan langsung kepada objek yang diteliti dengan tujuan memperoleh bahan yang berkaitan dengan penelitian.

\subsection{Teknis Analisa Data}

Analisis kualitatif yang digunakan oleh peneliti yaitu model analisis interaktif, yaitu model analisis yang membutuhkam tiga komponen berupa reduksi data, sajian data, serta penarikan kesimpulan/verifikasi dengan menggunakan interactive mode milik sugiyono.

1. Reduksi data

Mereduksi data bisa diartikan merangkum, memilih hal-hal yang pokok, memfokuskan pada hal-hal penting, dicari pola dan temanya [6]. Dengan mereduksi data akan memberikan gambaran yang lebih jelas, dan mempermudah peneliti untuk melakuakan pengumpulan data selanjutnya. Proses reduksi berlangsung terus selama pelaksanaan penelitian bahkan peneliti memulai sebelum pengumpulan data dilakukan dan selesai sampai penelitian berahir. Reduksi dimulai sewaktu peneliti memutuskan kerangka konseptual wilayah penelitian, permasalahan penelitian, dan pendekatan pengumpulan data yang digunakan. Selama pengumpulan data berlangsung, reduksi data dapat berupa membuat ringkasan, mengkode, memusatkan tema, membuat batas permasalahan, dan menulis memo.

2. Penyajian data

"Penelitian kualitatif penyajian data dilakuakn dalam bentuk uraian singkat, bagan, hubungan antar kategori, flowchart, dan sejenisnya", [6]. Sajian ini merupakan kalimat yang disusun secara logis dan sistematis, sehingga bila dibaca akan bisa mudah dipahami berbagai hal yang terjadi dan memungkinkan peneliti untuk berbuat sesuatu pada analisis ataupun tindakan lain berdasarkan pemahamannya tersebut. Sajian data ini harus mengacu pada rumusan masalah yang telah dirumuskan sebagai pertanyaan penelitian, sehingga narasi yang tersaji merupakan deskripsi mengenai kondisi yang rinci untuk menceritakan dan menjawab setiap permasalahan yang ada. Sajian data selain dalam bentuk narasi kalimat, juga dapat meliputi berbagai jenis matriks, gambar atau skema, jaringan kerja, kaitan kegiatan, dan juga tabel sebagai pendukung narasinya. Dengan melihat suatu penyajian data, peneliti akan melihat apa yang terjadi dan memungkinkan untuk mengajarkan suatu analisis ataupun tindakan lain berdasarkan penelitian tersebut.

3. Penarikan kesimpulan

Kesimpulan disini merupakan temuan baru dan belum pernah ada. Temuan masih berupa remang-remang dan menjadi jelas setelah diteliti, Simpulan perlu diverifikasi agar cukup mantap dan benar-benar bisa dipertanggungjawabkan [6].

Berdasarkan observasi yang dilakukan di lapangan peneliti menemukan bahwa bangunan yang didirikan dipinggir danau tondano Kecamatan Tondano Selatan itu sudah pernah di relokasi di sekitar kelurahan tersebut,pemerintah telah menyediakan perumahan untuk relokasi masyarakat, tetapi seiring berjalannya waktu menurut pendapat warga sekitar, ada pendatang yang membangun kembali bangunan di pinggir danau tersebut,peneliti mengajukan beberapa pertanyaan kepada dinas perizinan mengenai apa ada komunikasi atau pengawasan tentang kebijakan tersebut,staf bagian terkait perizinan mengatakan bahwa dana untuk sosialisasi tersebut belum kunjung datang.

\subsection{Keabsahan Data}

Pengujian keabsahan data,peneliti menggunakan 4 (empat) kriteria utama yang dikemukakan oleh Lincoln dan Guba guna menjamin keabsahan data penelitian kualitatif,yaitu [7]:

1. Derajat Kepercayaan (Creadibility)

Uji kredibilitas atau kepercayaan terhadap data hasil penelitian dilakukan dengan perpanjangan pengamatan, meningkatkan ketekunan, 
triangulasi, diskusi dengan teman sejawat, dan analisis kasus negative, dan member check.

2. Derajat Keteralihan (Transferbility)

Transferbility ini merupakan validitas eksternal yang menunjukkan derajat ketepatan. Peneliti dalam membuat laporannya harus memberikan uraian yang rinci, jelas, sistematis, dan dapat dipercaya. Dengan demikian maka pembaca menjadi lebih jelas atas hasil penelitian tersebut, sehingga dapat memutuskan dapat atau tidaknya untuk mengaplikasi hasil penelitian.

3. Derajat Ketergantungan (Dependability)

Dalam penelitian kualitatif, dependability disebut reliabilitas.Suatu penelitian yang reliable adalah apabila orang lain dapat mengulang/mereplikasi proses penelitian tersebut. Dalam penelitian kualitatif uji dependability dilakukan dengan melakukan audit terhadap keseluruhan proses penelitian. Bagaimana peneliti mulai menentukan masalah, memasuki lapangan, menentukan sumber data, melakukan analisis data, melakukan uji keabsahan data,sampai membuat kesimpulan harus dapat ditunjukkan oleh peneliti.

4. Derajat Kepastian (Confirmability)

Pengujian konfirmability dalam penelitian kualitatif disebut dengan uji obyektifitas penelitian. Peneliti dikatakan obyektif bila hasil penelitian telah disepakati banyak orang. Dalam penelitian ini, uji konfirmability mirip dengan uji dependability sehingga pengujian dapat dilakukan secara bersamaan. Menguji konfirmability berarti menguji hasil penelitian dikaitkan dengan proses yang dilakukan, maka penelitian tersebut telah memenuhi standar konfirmability. Dalam penelitian, jangan sampai proses tidak ada, tetapi hasilnya ada.

\section{Hasil dan Pembahasan}

\subsection{Gambaran Umum Lokasi Penelitian}

Secara geografis Kabupaten Minahasa memiliki luas 1.141,63 $\mathrm{km}^{2}$. Yang terdiri dari 227 desa, 43 kelurahan, dan 25 kecamatan. ibu kota Kabupaten Minahasa adalah Tondano, Jumlah penduduk Kabupaten Minahasa tahun 2019 adalah 342.110 jiwa. Batas wilayah Kabupaten Minahasa,sebagai berikut : Sebelah utara Laut Sulawesi, kota Manado dan kota Tomohon; Sebelah selatan Laut Maluku dan kota Tomohon; Sebelah barat Kabupaten Minahasa Selatan dan kota Tomohon; Sebelah timur Laut Maluku,Kabupaten Minahasa Utara dan kota Tomohon.

Visi dan Misi Kabupaten Minahasa yaitu :

- Visi: Minahasa Maju Dalam Ekonomi Dan Budaya,Berdaulat,Adil, dan Sejahtera

- Misi:
1. Meningkatkan Pembangunan

Sumber Daya Manusia Yang

Berbudaya Dan Berdaya Saing.

2. Mewujudkan Kemandirian

Ekonomi Dengan Mendorong Sektor Pertanian, Perikanan, Dan Pariwisata.

3. Mewujudkan Pengembangan Kewilayahan Dengan Prinsip Pembangunan Berkelanjutan.

4. Meningkatkan Pemerataan Kesejahteraan Masyarakat Yang Berkeadilan.

5. Memantapkan Managemen Birokrasi Yang Profesional Melalui Tata Kelola Pemerintahan Yang Baik.

\subsection{Deskripsi Hasil Penelitian}

3.2.1 Evaluasi Kebijakan Ijin Mendirikan Bangunan Di Kecamatan Tondano Selatan Kecamatan Tondano Selatan Kabupaten Minahasa

Agar terciptanya bangunan disempadan danau yang tertata dengan baik, memenuhi syarat dan tidak merusak lingkungan sekitar, pemerintah Indonesia mengeluarkan peraturan tentang ijin mendirikan bangunan, yang diatur dalam peraturan menteri pekerjaan umum dan perumahan rakyat republik Indonesia nomor 28/prt/m/2015 pasal 20 tentang penetapan garis sempadan sungai dan garis sempadan danau,juga diatur dalam peraturan daerah provinsi Sulawesi utara No.11 tahun 2006 tentang sempadan sumber air, dan juga diatur peraturan pemerintah No.36 tahun 2005 tentang bangunan gedung. Untuk mengetahui seperti apa Evaluasi kebijakan ijin mendirikan bangunan di Kecamatan Tondano Selatan kecamatan tondano selatan maka peneliti mengambil acuan dalam peraturan pemerintah No.36 tahun 2005 tentang bangunan gedung.

\subsubsection{Evaluasi Tujuan Dan Ukuran Kebijakan}

Berdasarkan hal diatas maka peneliti melakukan wawancara terkait Evaluasi kebijakan ijin mendirikan bangunan (IMB) di Kecamatan Tondano Selatan, dalam tahapan ukuran dan tujuan kebijakan kepada informan selaku Camat Kecamatan Tondano Selatan Kecamatan Tondano Selatan dengan memberikan pertayaan: "Bagaimana proses Evaluasi kebijakan ijin mendirikan bangunan di Kecamatan Tondano Selatan kecamatan tondano selatan?".

Berdasarkan wawancara kepada informan maka bisa dilihat dalam proses Evaluasi kebijakan ijin mendirikan bangunan di Kecamatan Tondano Selatan kecamatan tondano selatan seusia kenyataan dilapangan bahwa dalam indikator pertama ukuran dan tujuan suatu kebijakan belum terevaluasi dengan baik, baik dari segi ukuran maupun tujuan , 
kurangnya pengetahuan para aparat pemerintah tentang proses evaluasi kebijakan ijin mendirikan bangunan,menjadi suatu penghambat terevaluasinya kebijakan ijin mendirikan banguna ini dengan baik, bahkan masalah ini tidak hanya mencakup satu daerah atau desa saja tetapi seluruh daerah diindonesia masih mengalami permasalah yang sama.

\subsubsection{Sumber daya pendukung proses kebijakan}

Peneliti melakukan wawancara masih terkait dengan proses evaluasi kebijakan ijin mendirikan bangunan di Kecamatan Tondano Selatan kecamatan tondano selatan kabupaten minahasa, dalam indikator sumber daya pendukung kebijakan dengan pertayaan: "Bagaimana kesiapan pemerintah dalam mendukung kebijakan ini,apa langkah yang dilakukan pemerintah agar terciptanya sumber daya yang mampu menyelesaikan permasalahan dalam perizinan ini?

Dari pernyataan kelima informan dapat ditarik kesimpulan bahwa perizinan adalah suatu hal yang sangat penting,dalam mendukung kebijakan ijin mendirikan bangunan tersebut pemerintah telah melakukan berbagai cara tetapi untuk berberapa tahun terakhir belum ada tindakan lagi dari pemerintah,tidak bisa dipungkiri masalah pandemic ini juga salah satu penghambat terevaluasinya dengan baik suatu kebijakan termasuk kebijakan ijin mendirikan bangunan.

\subsubsection{Karakteristik Dan Sikap Agen Pelaksanan}

Untuk mengetahui bagaimana karakteristik atau sikap para implementor dalam mengevaluasikan kebijakan ijin mendirikan bangunan di Kecamatan Tondano Selatan peneliti melakukan wawancara kepada informan selaku Camat Kecamatan Tondano Selatan dengan pertayaan: "Bagaimana sikap dan tindakan bapak/ibu dalam mengevaluasi kebijakan ini?" dan dapat ditarik kesimpulan bahwa pemerintah berusaha semaksimal mungkin untuk menunjang proses evaluasi kebijakan ijin mendirikan bangunan hanya saja untuk sekarang belum ada tindakan langsung dari para implementor kebijakan.

\subsubsection{Komunikasi Antar Organisasi Dan aktivitas pelaksana}

Untuk mengetahui komunikasi antar organisasi dan aktivitas pelaksana kebijakan peneliti melakukan wawancara kepada informan CM selaku Kepala Bidang Pelayanan Perizinan Terpadu dengan pertayaan: "Apakah dalam proses evaluasi kebijakan ijin mendirikan bangunan ada komunikasi antar lembaga organisasi terkait , dan dengan masyarakat?" dan dapat disimpulkan bahwa sejauh ini belum ada sosialisasi dan tindakan dari pemerintah dalam mengatasi masalah perizinan ini.

\subsubsection{Lingkungan Ekonomi sosial dan politik Peneliti melakukan wawancara masih terkait dengan Evaluasi Kebijakan Ijin Mendirikan}

Bangunan Di Kecamatan Tondano Selatan Kecamatan Tondano Selatan Kabupaten Minahasa, kepada CM selaku Kepala Bidang Pelayanan Perizinan Terpadu dengan pertayaan: "bagaimana cara pemerintah dalam mengevaluasi kebijakan ijin mendirikan bangunan di Kecamatan Tondano Selatan diera pandemic,ekonomi sosial dan politik yang tidak menentu ini?" dan dapat disimpulkan bahwa keadaan ekonomi sosial dan lingkungan sekarang menjadi salah satu masalah bagi pemerintah untuk mengevaluasi kebijakan ijin mendirikan bangunan,karena bagaimana mereka mau mengurus perizinan kalau himbauan dari pemerintah pusat membatasi aktivitas masyarakat untuk keluar dari rumah kecuali untuk kepentingan yang memang sangat mengharuskan mereka untuk keluar dari rumah.

\section{Kesimpulan}

Berdasarkan hasil data penelitian yang telah diuraikan oleh peneliti dibab sebelemnya, maka dapat diambil kesimpulan yang dituangkan dalam penelitian ini yaitu:

1. Para aparat pemerintah kurang mengetahui tentang proses evaluasi kebijakan ijin mendirikan bangunan, bahkan pemerintah didinas perizinan kurang menguasai tentang peraturan ijin mendirikan bangunan

2. Dari sekian banyak Bangunan di Kecamatan Tondano Selatan yang berjumlah 350 hanya 10 bangunan yang telah memiliki izin

3. Kurangnya sosialisasi dari pemerintah membuat rendahnya kesadaran masyarakat dalam pengurusan ijin mendirikan bangunan di kecamatan tondano selatan

4. Sampai saat ini belum ada lagi tindakan dari aparatur pemerintah terkait bangunan yang tidak memiliki di kecamatan tondano barat karena dulu pernah dibuat perumahan untuk relokasi masyarakat disempadan danau tondano,namu dalam prosesnya kurangnya pengawasan pemerintah membuat hal yang sama terjadi kembali.

Pandemic virus corona membuat terhambatnya proses evaluasi kebijakan ijin mendirikan bangunan, karena terbatasnya aktivitas masyarakat diluar rumah dan dipekerjakannya pemerintah dirumah dan hanya melayani secara online membuat system pelayanan berbasis onlinetetapi itu juga menjadi tantangan tersendiri dari pemerintah.

\section{Referensi}

[1] V. Kumurur, "Aspek Strategis Pengelolaan Danau Tondano Secara Terpadu”, 2002. (https://konservasidanautondano.wordp ress.com manado 2019) 
[2] Peraturan Menteri Pekerjaan umum dan perumahan rakyat Republik Indonesia No.28 tahun 2015 Tentang Penetapan Garis Sempadan Danau.

[3] Peraturan Daerah Provinsi Sulawesi Utara No.11 Tahun 2006 Tentang Sempadan Sumber Air.

[4] Peraturan Pemerintah No.36 tahun 2005 Tentang bangunan Gedung.

[5] Creswell, "Research design: pendekatan kualitatif, kuantitatif, dan mixed," Yogjakarta: PT Pustaka Pelajar, 2010.

[6] Sugiyono, "Metode Penelitian Kuantitatif Kualitatif R\&D," Bandung: Alfabeta, 2012.

[7] Moleong, "Metodologi Penelitian Kualitatif. Edisi Revisi," Bandung : PT Remaja Rosdakarya, 2007. 